\title{
MoLearn, a Web-and Android-Based Learning Application as an Alternative for Teaching-Learning Process in High Schools
}

\section{J. Dewiyani Sunarto}

Dr, Institute of Business and Informatics Stikom Surabaya, Indonesia, dewiyani@stikom.edu

\section{Bambang Hariadi}

Dr, Institute of Business and Informatics Stikom Surabaya, Indonesia, bambang@stikom.edu

Tri Sagirani

Institute of Business and Informatics Stikom Surabaya, Indonesia, tris@stikom.edu

\section{Tan Amelia}

Institute of Business and Informatics Stikom Surabaya, Indonesia, meli@stikom.edu

\section{Julianto Lemantara}

Institute of Business and Informatics Stikom Surabaya, Indonesia, julianto@stikom.edu

$$
\text { | }
$$

The purpose of this study is to develop a Web- and Android-based learning application for high school students, named MoLearn. To meet teacher needs, a preliminary study was conducted by conducting interviews and field observations. The design and development follow the ADDIE model, with stages namely (1) analysis of needs, (2) design of interface, (3) development / construction, (4) implementation and (5) evaluation. The research subjects were educators who were members of the Biology and Geography MGMP, along with their students. The evaluation was carried out to the educators representing the respective MGMP, carried out by distributing questionnaires, and triangulation using the UI/UX test. Data analysis was performed with qualitative descriptive technique and descriptive statistic. Based on data analysis, the results show that all educators agree that (1) MoLearn's appearance is attractive and convenient to use, (2) MoLearn can fulfill learning needs, and (3) MoLearn has fulfilled the requirements as a learning model that utilizes Information Technology.

Keywords: learning application, web, android, molearn, teaching-learning process

Citation: Sunarto, M. J. D., Hariadi, B., Sagirani, T., Amelia, T., \& Lemantara, J. (2020). MoLearn, a Web-and Android-Based Learning Application as an Alternative for Teaching-Learning Process in High Schools. International Journal of Instruction, 13(1), 53-70. https://doi.org/10.29333/iji.2020.1314a 


\section{INTRODUCTION}

Currently, 2 important actors in learning process, namely educators and students, are played by 2 different generations. Educators are from generation X or Y, while students are from generation Z. (Ivanova \& Smrikarov, 2009) state that generation is a collection of people born within a certain range of years. Every generation is formed by the social and cultural communities in which it grows and is strongly influenced by available technological advancements. (M.Prensky, 2009) states that generation $\mathrm{Z}$ is the digital natives, namely generation that have been born and grown with the Internet, all equipment in life based on information technology, and they are the native speakers of technology, fluent in digital computer languages, video games, and Internet. While generation $\mathrm{X}$ or $\mathrm{Y}$ is referred to as the Digital Immigrants, because they were born before the widespread use of technology, so even though this generation has used technology, but the understanding and mastery is not as fluent as generation $\mathrm{Z}$.

(Prensky, 2011) says that digital natives are those born to have been in a digital environment and are familiar with computers, video games, internet and cell phones. It is also said that they have "hypertext thoughts", "jumping up and down", parallel and non-sequential cognitive structures. This means, they are accustomed to jumping cognitive structures but have a number of positive things such as being able to do/do several activities/tasks at the same time. They are able to listen to music while reading, while still being able to understand the reading they are reading, and on the sidelines, the activity is still while chatting with friends or while working on other assignments. The impression that was captured was that digital native was not focused on learning and carrying out activities. On the sidelines of learning and activities, they cannot be separated from their digital devices.

Digital native generation is a generation that cannot escape from technology (Mardina, 2011). This is felt when they do not have or obtain internet access as long as their existence is somewhere. Technology devices are confirmed to be connected to the internet so that they can always be connected with their siblings, or colleagues through SMS, WhatsApp, Facebook or other social media. In addition, technology devices also connect them to the tasks or work they save. They will feel comfortable when connected because it allows them to be able to do many things in a place.

Based on several literature studies on digital native (M.Prensky, 2009); (Mardina, 2011); ( $\mathrm{Ng}, 2012)$ it can be concluded that some native digital characteristics are as follows:

a. Do not like things that are slow, always prioritizing speed in using and receiving information. The Information must be present immediately

b. Able to work multitasking, because it is used to working on several things at once.

c. Don't like the information in the form of text, but tend to prefer images. In following the teaching and learning process, they prefer learning by doing activities and practices, rather than reading or listening.

d. Information processing is not linear, even jumping from one task to another. 
e. Love networking and collaborating, so that they will be able to work well in collaborative networks.

f. Expect technology to be part of his life, so that he feels difficult and uncomfortable without technology.

g. Want everything instantly, don't like the process.

(Prensky, 2011) describes Digital Immigrants as a generation not born at the time of the digital world, but that does not mean that this generation knows no technology at all, some use it because it must follow the progress of the times (Toledo, 2017). Some opinions state that the term Digital Immigrant is the opposite of Digital Native (Slyke, 2013). One of the characteristics of Digital Immigrants is a person's level of comfort with technology (M.Prensky, 2009); (Toledo, 2017). Another difference between Digital Natives and Digital Immigrants, besides age, is "intuitive acceptance of rapid digital change, because they have never been exposed to technology as much as digital natively, so they might have a harder time with continuous changes that often come with technology.

Since they come from two different generations, there must often be a gap between the two. At the high school level, the gap is obvious especially in the use of technology as a learning media. (Lisenbee, 2016) states that the factors that lead to inequality are due to the characteristics of 21 st century students, the ability of students to use technology independently, and teachers' perception of the technology itself.

Regarding the characteristics of 21st century students, (Grail, 2011);(Chalkiadaki, 2018); (Motallebzadeh, Ahmadi, \& Hosseinnia, 2018) states that students in the 21st century have distinct characteristics, they are (i) comfortable and highly dependent on technology, this is due to Generation $\mathrm{Z}$ being surrounded by technology, (ii) multitasking with a variety of online products and sophisticated technology equipment, as well as respect for simplicity and interactive design, (iii) having higher social responsibility with lots of information that can be accessed online, (iv) always connected, communicating through social, cross-country and cultural networks that indirectly affect the way of thinking and the decision making process. The typical characteristics of students in the 21 st century lead to gaps with educators because educators often feel that generation $\mathrm{Z}$ spends time too much with technological tools that are considered to have no benefit for the progress of their learning, while students as generation $\mathrm{Z}$ needs technology.

In fact, students as a generation $\mathrm{Z}$ use technology in all areas of their lives, both as learning and communication media, while many educators feel uncomfortable allowing students to independently explore and build their knowledge using technology, especially due to the lack of knowledge of educators about the use of technology. The gap between educators, expectations and use of technology by students in classes creates an incompatibility between educators and students, while these two actors should collaborate together for the success of teaching and learning process. 
It was revealed in the study of (Lisenbee, 2016) which states that $89 \%$ of educators who are the object of their research feel uncomfortable allowing students to use technology in the classroom, even though educators actually understand how technology can motivate students to learn and can demonstrate students understanding better. While research from (Lubis, 2018) shows that although ICT integration has an impact on positive perceptions of the existence of ICT, the subjects view that the benefits of integration are still focused on the technical level, not on communicative and functional aspects in learning process, and the allocation of time and technical problems are the main obstacles to implement the integration.

The impact of these gaps is quite alarming. Between educators and students there are often misunderstandings, students access their gadgets to get more information than what has been provided by educators, while educators interpret them to be playing and do not pay attention to the lessons. Often educators are embarrassed because it turns out that students have more knowledge, while educators still have limited knowledge. This is because educators are unable to keep up with technology, which, if used wisely, can bring many benefits.

If observed in detail, there are so many advantages due to the development of information technology. (Herayanti, Fuadunnazmi, \& Habibi, 2017), (Aghajani \& Adloo, 2018) states that the use of communication and information technology in the field of education has very great effect. In the learning process there is a tendency that allows education to be student-oriented, education can occur not only in schools, and the increasing number of learning resources choices to enrich students' knowledge.

By having awareness of the gap between the two important actors in the world of education and the importance of information technology in learning, and in order to overcome these gaps, a tool is made that can facilitate learning for students and facilitate teaching for educators. The tool is expected in the form of a technology-based application. This is because one of the developing technological outcomes, especially among students is communication technology, shown by the highest gadget users at the age of 15 to 19 years (Qumillaila, Susanti, \& Zulfiani, 2017). While (Herayanti, Fuadunnazmi, \& Habibi, 2017) believe that the application will be able to increase motivation and learning outcomes of students, because it is very possible that educators not only have learning resources from teachers, but also from fellow students and other learning resources. According to (Ivanova \& Smrikarov, 2009) learning with an application that is able to involve students in their world will make students more interested because it suits their daily lives. This is because students from generation $\mathrm{Z}$ cannot be separated from cyberspace, always want to get new information, and are very comfortable with gadgets or laptops that are connected to internet network.

Learning application made does not mean leaving the role of educators behind, instead educators must play more roles to create conducive learning. (Sunarto, Hariadi, Sagirani, \& Amelia, 2017) state that educators must begin to think of a learning model that can align themselves with students' needs, which always follows the rapid development of today's gadgets. Even so, this also does not mean leaving the 
conventional method behind, i.e face to face, because a touch of humanity is still needed. This concept is often referred to as Hybrid Learning.

The thing to remember in creating the application is that the learning application must not be created merely based on the observations and needs of the application maker, but must be based on the needs of the application user. (Sadeghi, 2017) states that the learning application made must be relevant to the cultural context where it will be applied. To achieve great success from a learning application, it must be based on the characteristics, technology and context of learning system.

In order to create an application that fits user's needs, the right approach must be chosen. The approach to compiling learning applications must be based on user needs, so that it can be used in accordance with the objectives of learning.

The aim of this study is to determine the needs of learning media for users, i.e. educators and students at high school level, so that the learning application made can be a bridge for the two main actors in teaching and learning process, and eventually it can create class that is comfortable and able to improve outcome and quality of learning.

\section{METHOD}

This research, aiming at of creating a web- and android-based learning application for High School level, followed a gradual research development. It was utilized from the ADDIE model (analysis, design, development, implementation and evaluation) in the stage of the research.

The ADDIE model is one of the most commonly used models in the field of instructional design in order to produce effective design (Aldoobie, 2015). It helps instructional designers, any content developers, or even teachers to create efficient and effective teaching designs. In fact, the elements made using the ADDIE model can be used in any environment, whether online or face to face. Each stage in the ADDIE model is related/interrelated and interacted with each other.

The problem to be solved in this study is to build Web- and Android-based learning application based on effective and interesting learning models. To solve the problem, the first stage that should be followed is to analyze the needs and determine the concepts of web- and android-based learning application. In the second stage, the design of interface will be completed on web- and android-based learning application. In the third stage, construction is carried out, then the fourth stage, the application will be implemented and evaluated the web- and android-based learning application. In detail, the stages of research activities can be seen in table 1 below. 
Table 1

Stage of Activities for Creating Web- and Android-Based Learning Application with ADDIE Model

\begin{tabular}{|c|c|c|c|}
\hline No & Stage & Activity & Output \\
\hline 1. & $\begin{array}{l}\text { Analysis of } \\
\text { Needs }\end{array}$ & $\begin{array}{l}\text { Steps taken: Analysis of students. } \\
\text { At this stage, students' needs in order to get an adequate learning } \\
\text { environment must be determined. } \\
\text { Analysis of Instructional Objectives. } \\
\text { At this stage, clear objectives must be identified for specific } \\
\text { instructions, so it can save a lot of time, energy and be more } \\
\text { targeted. } \\
\text { At the end of the analysis of needs, it must be clearly known about } \\
\text { the objectives and what will be mastered by students. }\end{array}$ & $\begin{array}{l}\text { Process flow chart } \\
\text { Results of elicitation } \\
\text { Document of menu } \\
\text { needs }\end{array}$ \\
\hline 2. & Design & $\begin{array}{l}\text { The design stage is the next step in the ADDIE model. This stage } \\
\text { talks about applying instructions. There are } 2 \text { designs that must be } \\
\text { completed, namely } \\
\text { a. Design of assessment. Assessing the learning outcomes of the } \\
\text { subject is very important but beforehand the design and the right } \\
\text { tools must be chosen to be able to make an assessment. } \\
\text { b. Design of learning forms. At this stage the form of the class will } \\
\text { be chosen, whether online or face-to-face. } \\
\text { c. Creating instructional strategies. }\end{array}$ & Design of interface \\
\hline 3. & Development & Arrange functions on each menu. & $\begin{array}{l}\text { a. Function document } \\
\text { b. Web- and Android- } \\
\text { Based Learning } \\
\text { Application }\end{array}$ \\
\hline 4. & Implementation & $\begin{array}{l}\text { Conduct training for users. } \\
\text { Prepare students } \\
\text { Prepare a condusive learning environment. }\end{array}$ & $\begin{array}{l}\text { Training book. } \\
\text { Infrastructure checklist }\end{array}$ \\
\hline 5. & Evaluation & $\begin{array}{l}\text { Test the application on educators through questionnaires and design } \\
\text { testing }\end{array}$ & $\begin{array}{l}\text { a. Questionnaire } \\
\text { document } \\
\text { b. Evaluation result }\end{array}$ \\
\hline
\end{tabular}

\section{FINDINGS}

\section{Analysis of Needs}

In order to be able to do an analysis of students and instructional objectives well, the researcher must make analysis of needs by fully involving both teachers and students. The method used is the PAR (Participation Action Research) method. In the PAR method, there are 7 steps to make analysis of needs (Watters, Commeau, \& Restall, 2010), they are:

\section{(1) Determining the objective}

In this study, the proponent-researcher group has objective to make a real contribution to the development of education in Indonesia, due to technological advances faced by today's generation. Therefore, the proponent-researchers went to the East Java Provincial Education Office, more specifically to the groups of Biology's teachers (MGMP Biology) and the groups of Geography's teachers (MGMP Geografy) of East Java Province, to determine problems occurred in the world of education. By knowing the problems occurred, it was expected that the group of proponent-researchers and partners will be able to achieve the objective set. 
Some points that can be concluded from the results of intensive interviews with teachers who are members of MGMP Biology and MGMP Geography as partners (represented by 6 teachers for each MGMP), are as follows:

a) An application is needed that can be used as a learning medium for students, but it should also be easy to use for educators.

b) The application must be able to anticipate IT developments for the next several years and it will not be outdated within a few years.

c) The program must be user friendly not only for students, but also for educators.

d) The application can be oriented to several applications that have been existing today, including Quipper School, with some improvements, for example in Quipper it is not able to display questions randomly, and there is no deadline for collecting exams.

e) It should be equipped with analysis of question items, the application for tests is divided into daily tests, summative tests and others, and the value report is linked to the database.

f) The application should be both Web- and Android-based, so it can be accessed anywhere and anytime.

\section{(2) Determining partners to conduct research}

In a study with PAR, members of research team is very likely to be taken from outside the group of researchers, because a study often requires additional expertise in addition to those that have been mastered by the team (E, Kramer, Kramer, \& Hammel, 2009). In this study, the research group collaborated with the East Java Provincial Education Office, more specifically with the MGMP Biology and MGMP Geography groups of East Java Province, as the pilot project of two subjects to be applied, representing Natural Sciences, and Social Science groups. In each stage of the research, the group of researchers together with the MGMP groups were active in the activity program, starting from analysis of needs, design, development, to implementation and evaluation.

\section{(3) Collecting the information data}

This step will clarify how the proponent researcher group collect data to obtain information (E, Kramer, Kramer, \& Hammel, 2009). The most common way is through interviews, surveys, questionnaires, and so on. Research groups must be able to decide correctly, which is the most appropriate way to get information. In this study, the research group decided to obtain data through intensive interviews with the MGMP groups as research partners, to find out the problems in the world of education, especially in addressing the development of information technology. Intensive interviews are needed so researchers can find out the exact application needs.

\section{(4) Processing the information data}

Processing data is important in order to get answers to questions; therefore, research groups must decide which method is most possible to analyze and interpret the data that 
has been collected (Schneider, et al., 2004). At the time of data processing, the research partners, in this case the MGMP, must be fully involved step by step, in order to provide careful consideration, whether the data can be used appropriately, and provides useful information or not.

\section{(5) Presentation of results of processing information data}

At this stage, the proponent-researcher group tries to present the results of the data interpretation that was made in step (5). Presentation techniques must be made so that partners can understand the results that have been obtained well (Schneider, et al., 2004). The technique chosen must be appropriate, according to the invited audiences. In this study, because the partner groups are MGMP teachers, and presenting the results is about a web- and android-based learning application, then in the presentation, the proponent-research group must use a language that can be understood by general people.

\section{(6) Implementing data processing results}

From the web and Android-based learning application plan that has been presented, then the application was piloted in several schools, in accordance with the appointment of the East Java Provincial Education Office as partner and advisor. The Provincial Education Office is the determinant, because it knew what schools can be used as trials (Schneider, et al., 2004).

\section{(7) Evaluation}

The last step is to make an evaluation of the results of data processing, so it can obtain a conclusion about the effectiveness of learning process using the application that has been created, and some menus that must be improved (E, Kramer, Kramer, \& Hammel, 2009).

\section{Design of Interface}

In the Design of the Interface arrangement for Web- and Android-based learning applications, the Frame Model was used. According to (Sagirani, Sunarto, Hariadi, \& Amelia, 2017) in building a mobile-based learning, there are some aspects that must be considered; technical characteristics of mobile devices to be used, social learning and personal aspects. A suitable model for this arrangement is the FRAME model, because this model specializes in the role of technology in learning. In the FRAME model, the information context becomes an astounding learning experience, using mobile devices.

Students will create while consuming information, which is then mediated through existing technology, so that it is more meaningful and useful.

The aspects used in the FRAME model are device (D), learners (L) and social (S), plus the combinations between device usability (DL), social technology (DS) and interactions learning (LS) (Koole, 2009). All of these aspects are translated into a planning.

The three main aspects to be discussed are the device (D), students (L) and social (S) aspects. From processing the three main aspects, a design was drafted on the implementation of mobile learning, named MoLearn. (Sagirani, Sunarto, Hariadi, \& 
Amelia, 2017), designed the implementation of mobile learning as shown in Figure 1. Figure 1 below is a sitemap that organizes menus and menu distribution for each user in the MoLearn application is divided into MGMPs, Teachers and Students.

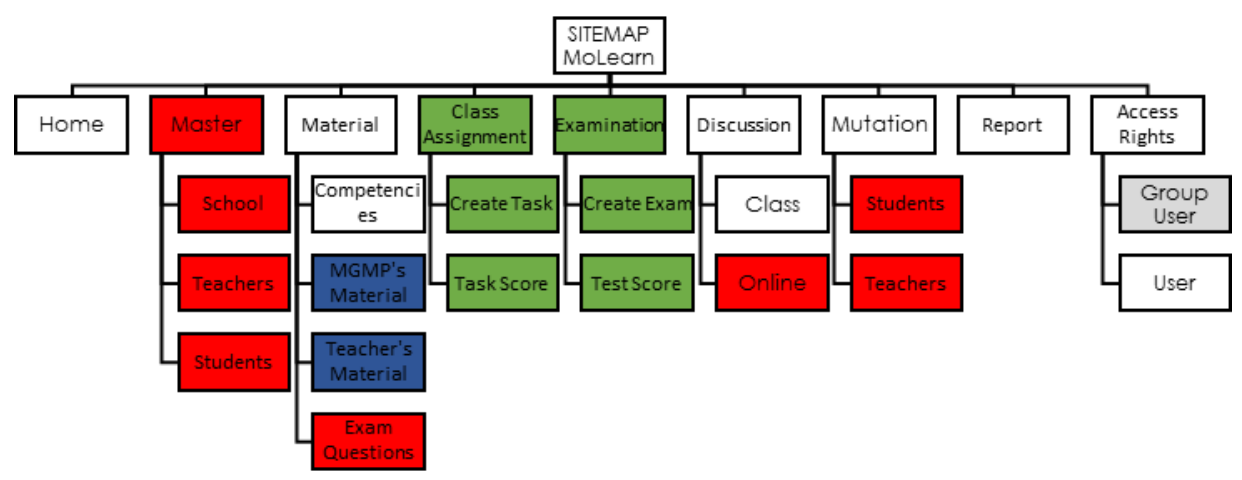

Figure 1

MoLearn Menu Design (Sagirani, Sunarto, Hariadi, \& Amelia, 2017)

The above menu design is utilized in MoLearn application in two versions, web-based and Android-based, respectively. With the main menu consists of home, master, material, class assignment, examination, discussion, report and right for access.

\section{Design and Construction}

Based on the results of interviews with research partners, a Web- and Android-based learning application was made so that educators can do Hybrid Learning in the classroom.

The overview and basic menu in the learning application named MoLearn are:

\section{Overview}

MoLearn or Mobile Learning is a media created to support teaching and learning activities in schools. MoLearn, which has meaning of learning anywhere, has the advantage of being able to be accessed anywhere through gadget media (laptops, smartphones, tablets, computers) with internet connection support. This learning media facilitates interaction between teachers and students to provide and obtain learning materials, provide and collect assignments, train on online examinations, and conduct discussions. In addition to teachers and students, MoLearn was made for MGMP to control learning materials so that with this media students are expected not to get deviant materials. 


\section{Basic menu on MoLearn}

MoLearn's website is divided into 3 parts, MGMP (MGMP administrators), teachers, and students. Each section has a different menu according to the data and information needed and what can be done on the MoLearn website.

\section{Menu for MGMP}

MGMP administrators have a role as data providers and class organizer. The basic menu in the MoLearn application for MGMP consists of: (1) Home Page, (2) Home, (3) Master of School, (3) Master of Teacher, (4) Master of Student, (5) Master of Regional, (6) Academic Year , (7) Competencies, (8) MGMP Material, (9) Teacher Material, (10) Exam Questions, (11) Discussion Categories, (12) Student Movements, (13) Teacher Movements, (14) Announcements, (15) Group User, (16) User.

\section{Menu for teachers}

The MoLearn application on teachers' side has a function as a local content provider or additional content to be given to students in their classes and to make and organize assignments and examinations for students. The basic menu in the Molearn application for teachers consists of: (1) Home, (2) My Class, (3) Competencies, (4) MGMP's Material, (5) Teacher's Material, (6) Create Task, (7) Task Score, (8) Create Exam, (9) Test Score, (10) Class Discussion, (11) MGMP Teacher Discussion.

\section{Menu for students}

The MoLearn application on students' side has a function as a place to take material, collect assignments, and also do exams and discuss with classmates and teachers. The basic menu in the Molearn application for students consists of (1) Home, (2) MGMP's Material, (3) Teacher's Material, (4) Classroom Task, (5) Exam, (6) Class Discussion.

\section{Testing and Implementation}

\section{Evaluation results from educators}

After the MoLearn learning application was completed, an explanation was given to the educators of Biology and Geography subjects who were members of the MGMP, as the main resource persons to produce this learning application. After an explanation in the form of intensive training and workshops on the use of the MoLearn application, the educators of Biology and Geography subjects who were members of the MGMP were asked to fill in assessment of the appearance of MoLearn both on Web and Android.

Educators were asked to assess the 3 components, namely (1) Assessment of the MoLearn application both on Web and Android versions, (2) Assessment of the benefits of MoLearn both on Web and Android for MGMP, (3) Assessment of MoLearn on Web version as Learning Prototype for MGMP.

\section{Measurement results of user experience questionnaire (UEQ)}

In addition to assessing MoLearn's appearance, MGMP administrators were also asked to assess User Experience Questionnaire (UEQ). UEQ is a process of increasing the 
satisfaction of users (application users, website visitors) in enhancing usability and pleasure given in interactions between users and products (Sunarto, Hariadi, Sagirani, \& Amelia, Initialization Requirement in Developing of Mobile Learning 'Molearn' for Biology Students Using Inquiry-based learning, 2017). The results of trials based on User Experience Questionnaire (UEQ), are:

Table 2

User Experience Questionnaire Results

\begin{tabular}{lll}
\hline Scale & Excellent & Mean \\
\hline Attractiveness & 0,78 & 2,32 \\
Clarity & 0,68 & 1,85 \\
Efficiency & 0,86 & 2,125 \\
Dependability & 0,90 & 2,175 \\
Stimulation & 1,00 & 2,45 \\
Novelty & 1,16 & 2,15 \\
\hline
\end{tabular}

If presented in graphical form, then the results of User Experience Questionnaire on the MoLearn application can been seen in figure 2:

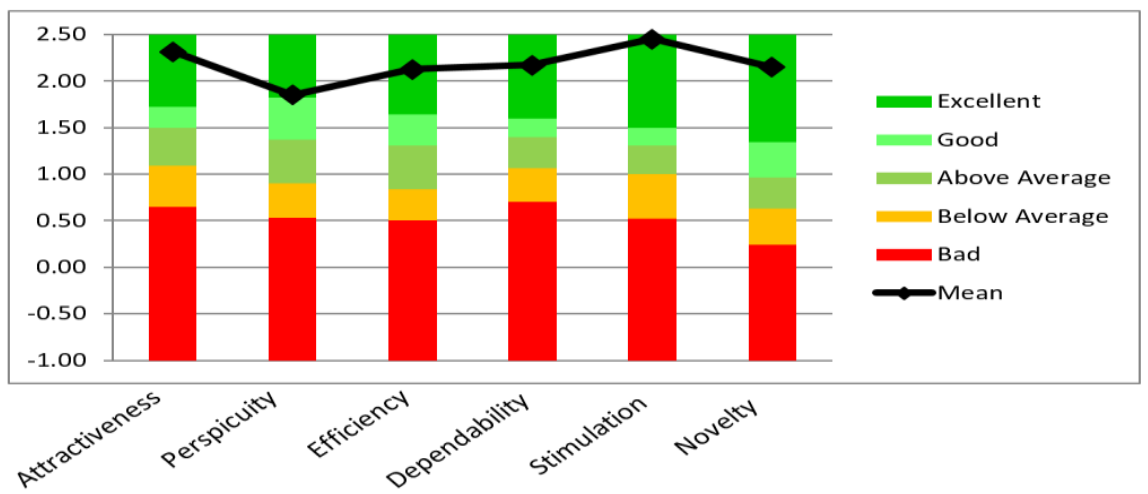

Figure 2

UEQ Graphic Results

From the UEQ graphic results on educators, it can be seen that the results obtained are in the Excellent range, which means the results are in accordance with those obtained from the results of the questionnaire.

\section{Classroom learning results}

After obtaining questionnaires from MGMP administrators as researchers' partners and the User Experience Questionnaire results for the MoLearn application, the MoLearn application was tested limited to one Basic Competency, in one class at one of Surabaya Senior High Schools for Biology subjects for one semester. While one other class was used as a conventional class, in order to compare student learning outcomes in classes without and with MoLearn. Data for each class are: 
Table 3

Number of Students in Each Class

\begin{tabular}{ll}
\hline Class & Number of respondents \\
Without MoLearn & 37 \\
With MoLearn & 40 \\
\hline
\end{tabular}

\section{DISCUSSION}

\section{Results of Questionnaire to MGMP Administrators}

According to (Riduwan, 2012), one of the questionnaire functions is to be able to provide an overview of characteristics of a group of respondents. In this study, the characteristic description to be achieved is on the appearance, benefits, and functions of the MoLearn application, both on Web and Android versions as learning prototypes.

The questionnaire given was closed-end and open-end. The results of open-end questionnaire were quantitative data in the form of numbers, with the type of measurement scale in the form of interval scale, starting from 5 for SA (strongly agree), 4 for A (agree), 3 for $\mathrm{N}$ (neutral), 2 for D (disagree), and 1 for SD (strongly disagree). This interval scale was chosen because this scale is most often used to measure symptoms in social research (Riduwan, 2012).

The type of interval measurement scale here is a measurement scale to measure the scale of social participation (Riduwan, 2012). The scale used in attitude measurement in this study was 5-point Likert Scale.

The Likert Scale was used to measure the teachers who were members of MGMP about their opinions or perceptions of Web- and Android-based MoLearn application. By using a Likert scale, the variables to be measured are translated into dimensions, dimensions are translated into sub-variables, then sub-variables are translated again into measurable indicators. Finally, this measurable indicator can be used as a starting point for making instrument items in the form of questions or statements that need to be answered by respondents. Each answer is associated with a form of question or support expressed by the following words:

$\mathrm{SA}=$ Strongly Agree, score $=5$

$\mathrm{S}=$ Agree, score $=4$

$\mathrm{N}=$ Neutral, score $=3$

$\mathrm{D}=$ Disagree, score $=2$

$\mathrm{SD}=$ Strongly disagree, score $=1$

In this study, the instrument was distributed to 12 respondents, then it was recapitulated.

On each item, the highest score for each item is: $5 \times 12=60$

While the lowest score is: 1 x $12=12$ 
Because the lowest score is 12 and the highest score on each item is 60 , the interval scale can be made as follows:

Table 4

Scale of Scores on Items and Their Predicates

\begin{tabular}{ll}
\hline Scale of scores on items & Predicates \\
\hline $12-22$ & Strongly disagree \\
$23-32$ & Disagree \\
$33-42$ & Neutral \\
$43-52$ & Agree \\
$53-62$ & Strongly Agree \\
\hline
\end{tabular}

From the results of the questionnaire conducted, it turns out that all scores obtained were ranged from 43-52, so that the results showed that all teachers who were members of the MGMP agreed to all items assessed in the web and the Android version of the MoLearn learning application. This means, the teachers agree that the MoLearn application, both web and android versions, is (1) attractive in its appearance and comfortable to use, (2) able to fulfill learning needs, and (3) having quality as a learning model that utilizes Information Technology.

This is also revealed by (Benson, Anderson, \& Ooms, 2011) from the research results on teachers, the results obtained state that using learning applications for hybrid learning, will expand the material to meet learning needs. While (Cochrane, 2010) states that teachers express the importance of pedagogical technology integration into course assessments, lecturer modeling and pedagogical use of tools and needs. (Peacock, Robertson, Williams, \& Clausen, 2009). Meanwhile, (Aubusson, Schuck, \& Burden, 2009), (Shabrina \& Kuswanto, 2018) also use an approach to teachers and students when compiling learning application in their schools.

\section{Results of Students' Pre- and Post-test Scores}

From the results of the pre-test and post-test scores of students, it will be investigated whether there are differences between the classes used and did not use the MoLearn application. In this case, we used $\propto=5 \%$

\section{Normality test}

Table 5

Normality Test of Biology Classes with and without MoLearn Tests of Normality

\begin{tabular}{llllllll}
\hline & & \multicolumn{9}{l}{ Kolmogorov-Smirnova } & \multicolumn{3}{l}{ Shapiro-Wilk } & \\
\cline { 3 - 8 } Group & Statistic & df & Sig. & Statistic & df & Sig. \\
\hline \multirow{2}{*}{ Value } & With MoLearn & .101 & 37 & $.200^{*}$ & .952 & 37 & .111 \\
& Without MoLearn & .110 & 40 & $.200^{*}$ & .963 & 40 & .220 \\
\hline
\end{tabular}

*. This is a lower bound of the true significance.

a. Lilliefors Significance Correction 
Based on the output test of normality, it can be seen that the p-value for the class with MoLearn is 0.111 , which means that the $\mathrm{p}$-value $>\alpha(\mathrm{H} 0$ is accept), this indicates that the data of the class used MoLearn are normally distributed. While the test of normality for the class without MoLearn is 0.220, which means that the p-value $>\alpha$ ( $\mathrm{H} 0$ is accepted), this indicates that the data of class groups that did not use MoLearn are normally distributed.

\section{Homogeneity test}

Table 6

Homogeneity Test of Biology Classes with and without MoLearn

Test of Homogeneity of Variances

\begin{tabular}{cccc}
\hline Value & & & \\
\hline Levene Statistic & df1 & df2 & Sig. \\
\hline 5.492 & 1 & 75 & .022 \\
\hline
\end{tabular}

Based on the output of the homogeneity test of variance, it can be seen that the p-value for the test is 0.022 , which means that the $\mathrm{p}$-value $<\alpha$ (H0 is rejected), this indicates that the data of the class used MoLearn and the one that did not use MoLearn are not homogeneous.

Because the data is normal but not homogeneous, the next step taken was performing test on the hypothesis using the Mann Whitney Test.

\section{Mann Whitney test}

Table 7

Mann Whitney Test

\begin{tabular}{ll}
\hline Test Statistics & Score \\
\hline Mann-Whitney U & 483.500 \\
Wilcoxon W & 1303.500 \\
$\mathrm{Z}$ & -2.617 \\
Asymp. Sig. (2-tailed) & .009 \\
a. Grouping Variable: Group
\end{tabular}

Based on the test statistics output, it can be seen that the p-value is 0.009 which means that the p-value $<\alpha$ (H0 is rejected), it can be concluded that there is a difference between classes with and without MoLearn in their learning process.

\section{Description of test result}

After finding out that there is difference, the results of the tests between the classes with and without MoLearn will be described.

Table 9

Average Score of Biology Subject

\begin{tabular}{llllll}
\hline Class & $\begin{array}{l}\text { Number } \\
\text { respondents }\end{array}$ & $\begin{array}{l}\text { Pre-test } \\
\text { Score }\end{array}$ & Post-test Score & Difference & N Gain \\
\hline Without MoLearn & 37 & 48.1 & 68.1 & 20 & 0.63 \\
\hline With MoLearn & 40 & 38.43 & 69.08 & 30.65 & 0.99 \\
\hline
\end{tabular}


From the data in Table 9 above, it gives an overview of the differences in learning outcomes obtained by classes with and without MoLearn. The differences in the average scores of the pre-test and post-test of the MoLearn class is higher than the Non MoLearn class. This means that there is a higher increase in learning outcomes after learning using MoLearn.

This is in line with research by (Crampton, Ragusa, \& Cavanagh, 2012) which state that first-year students in Arts and Science department get better results when students more often utilize learning applications in their school. While (Wright \& Parchoma, 2011) suggest to use application as a learning model in school, because it can improve student learning outcomes.

\section{CONCLUSION}

Based on the explanation of the results of the research and discussion above, it can be concluded that by using ADDIE Model, a Mobile Learning application has been successfully developed for high school students, and has been evaluated with the results:

(1) All teachers "agree" that (a) the appearance of MoLearn is attractive and comfortable to use, (b) MoLearn can fulfill learning needs, and (c) MoLearn has fulfilled the requirements as a learning model utilizing Information Technology.

(2) From the results of UEQ on educators, it can be seen that the results obtained are in the Excellent range, which means the results are in accordance with those obtained from the results of the questionnaire.

(3) The difference in the average scores of the pre-test and post-test in the MoLearn class is higher than the Non-MoLearn class. This means that there is a higher increase in learning outcomes after using MoLearn for learning process.

\section{ACKNOWLEDGEMENT}

Thank you to the Directorate of Research and Community Service, the Directorate General of Research and Development of the Ministry of Research, Technology and Higher Education who has funded this research through the National Institutional Strategic Program (PSNI) for two years. Acknowledgments are also conveyed to the MGMP Biologi and MGMP Geographi for their active participation, until the application has been completed, and also to the East Java Provincial Education Office for allowing and willing to use this learning application. This work was also supported by Institute of Business and Informatic Stikom Surabaya.

\section{REFERENCES}

Aghajani, M., \& Adloo, M. (2018). The effect of online cooperative learning on students' writing skills. International Journal of Instruction, 11(3), 433-448. doi: 10.12973/iji.2018.11330a.

Aldoobie, N. (2015). ADDIE model. American International Journal of Contemporary Research, 5(6), 68-72. 
Aubusson, P., Schuck, S., \& Burden, K. (2009). Mobile learning for teacher professional learning: Benefits obstacles and issues. ALT-J, Research in Learning Technology, 17(3), 233-247. doi: 10.1080/09687760903247641.

Benson, V., Anderson, D., \& Ooms, A. (2011). Educators' perceptions, attitudes and practices: Blended learning in business and management education. Research in Learning Technology, 19(2), 143-154.

Chalkiadaki, A. (2018). A systematic literature review of 21 st century skills and competencies in primary education. International Journal of Instruction, 11(3), 1-16. doi: 10.12973/iji.2018.1131a.

Cochrane, T. D. (2010). Exploring mobile learning success factors. ALT-J, Research in Learning Technology, 18(2), 133-148. doi: 10.3402/rlt.v18i2.10758.

Crampton, A., Ragusa, A. T., \& Cavanagh, H. (2012). Cross-discipline investigation of the relationship between academic performance and online resource access by distance education students. Research in Learning Technology, 20, 1-14. doi: 10.3402/rlt.v20i0/14430.

Delialioğlu, Ö. (2012). Student engagement in blended learning environments with lecture-based and problem-based instructional approaches. Educational Technology \& Society, 15(3), 310-322.

Grail. (2011, November). Consumers of tomorrow: Insights and Observations About Generation Z. Retrieved from https://www.slideshare.net/johnyvo/consumers-oftomorrowinsightsandobservationsaboutgenerationz-25226677.

Herayanti, L., Fuadunnazmi, M., \& Habibi. (2017). Developing moodle-based learning media for basic physics. Cakrawala Pendidikan, XXXVI(2), 210-219. doi: 10.21831/cp.v36i2.13077.

Ivanova, A., \& Smrikarov, A. (2009). The new generations of students and the future of e-learning in higher education. In International Conference on e-Learning and the Knowledge Society - e-Learning'09 (pp. 20-28). London: Core UK.

Koole, M. L. (2009). A model for framing mobile learning. Edmodo AB: AU Press.

Kramer, E. G. I., Kramer, J. M., \& Hammel, J. (2009). Who did what: A participatory action research project to increase group capacity for advocacy? Journal of Apllied Research in Intellectual Disability, 22(1), 10-22. doi: 10.1111/j.14683148.2008.00431.x.

Lisenbee, P. S. (2016). Generation gap between students' needs and teachers' use of technology in classrooms. Journal of Literacy and Technology, 17(5), 99-123. 
Lubis, A. H. (2018). ICT integration in 21st-century Indonesian English language teaching: Myths and realities. Cakrawala Pendidikan, XXXVII(1), 13- 26.

Mardina, R. (2011). Potential of digital natives in the representation of web-based multimedia information literacy in higher education. Jurnal Pustakawan Indonesia, 515.

Motallebzadeh, K., Ahmadi, F., \& Hosseinnia, M. (2018). Relationship between 21st century skills, speaking and writing skills: A structural equation modelling approach. International Journal of Instruction, 11(3), 265-276. doi: 10.12973/iji.2018.11319a.

$\mathrm{Ng}$, W. (2012). Can we teach digital natives digital literacy? Computers \& Education, 59(3), 1065-1078. doi: 10.1016/j.compedu.2012.04.016.

Peacock, S., Robertson, A., Williams, S., \& Clausen, M. G. (2009). The role of learning technologists in supporting e-research. ALT-J, Research in Learning Technology, 17(2), 115-129.

Prensky, M. (2001). Digital natives, digital immigrants part 1. On the Horizon, 9(5), 16. doi: $10.1108 / 10748120110424816$.

Prensky, M. (2009). Shaping tech for the classroom. Retrieved from http://wwwedutopia.org/adopt-and-adapt-shaping-tech-for-classroom.

Qumillaila, Susanti, B. H., \& Zulfiani. (2017). development of the android version of augmented reality. Cakrawala Pendidikan, 57-69.

Riduwan, D. M. (2012). Skala pengukuran variabel-variabel penelitian. Bandung: CV Alfabeta.

Sadeghi, S. H. (2017). E-learning practice in higher education: A mixed method comparative analysis. Switzerland: Springer.

Sagirani, T., Sunarto, M. D., Hariadi, B., \& Amelia, T. (2017). Frame model in android based molearn applications. Proceedings of the national conference on teachers and educational innovation (pp. 320-332). Tabanan, Bali: Undhiksa Press.

Schneider, B., Scissons, H., Arney, L., Benson, G., Derry, J., Lukas, K., . . Sunderland, M. (2004). Communication between people with schizophrenia and their medical professional: A participatory research project. Qualitative Health Research, 14(4), 562577.

Shabrina, \& Kuswanto, H. (2018). Android-assisted mobile physics learning through Indonesian Batik. International Journal of Instruction, 11(4), 287-302. doi: 10.12973/iji.2018.11419a. 
Slyke, T. V. (2013). Digital natives, digital immigrants: Some thoughts from the generation gap. Retrieved from https://depd.wisc.edu/html/TSarticles/Digital\%20Natives.htm.

Sunarto, M. D., Hariadi, B., Sagirani, T., \& Amelia, T. (2017). Application of participation action research approach in making "molearn" learning application for East Java high school MGMP. In Indonesian National Teachers Conference, (pp. 1-10). Tabanan.

Sunarto, M. D., Hariadi, B., Sagirani, T., \& Amelia, T. (2017). Initialization requirement in developing of mobile learning 'molearn' for biology students using inquiry-based learning. In the 2017 IEEE International Conference on Applied System Innovation - IEEE-ICASI 2017, (pp. 1865-1867). Osaka.

Toledo, C. A. (2017). Digital culture: Immigrants and tourists. International Journal of Teaching and Learning in Higher Education, 19(1), 84-92.

Watters, J., Commeau, S., \& Restall, G. (2010). Participation action research: An educational tools for citizen users community mental health metal services. MC Dermot Avenue: Universitas of Manitoba Press.

Wright, S., \& Parchoma, G. (2011). Technologies for learning? An actor-network theory critique of 'affordances' in research on mobile learning. Research in Learning Technology, 19(3), 247-258. doi: 10.3402/rlt.v19i3.17113. 